\title{
Cystic Echinococcosis: One Entity, Two Unusual Locations
}

\section{Kistik Ekinokokkoz; Bir Hastalık, İki Sıra Dışı Yerleşim}

Yeşim Sağlıcan', Özben Yalçın², Ecmel Kaygusuz ${ }^{3}$

${ }^{1}$ Acıbadem Üniversitesi Tıp Fakültesi, Patoloji Anabilim Dalı, İstanbul, Türkiye

2Sağlık Bakanlığı Şişli Hamidiye Etfal Hastanesi, Patoloji Bölümü, İstanbul, Türkiye

${ }^{3}$ Sağlık Bakanlığı Zeynep Kamil Hastanesi, Patoloji Bölümü, İstanbul, Türkiye

\section{ABSTRACT}

We report two cases of cystic echinococcosis at unexpected locations. Patients were a 64-year-old man and 35-year-old woman. A cystic mass was incidentally found between the prostate and seminal vesicles in the male patient, using ultrasonography during a check-up for ischemic coronary disease. The female patient was admitted to the hospital with symptoms of cardiopulmonary disease, but her detailed radiological examination showed a cystic lesion in the interventricular septum of the heart. Both patients were operated, and examinations of the histologic sections revealed cyst walls consistent with echinococcal infection. Attention should be focused on this entity even in endemic areas, and pathologists should be aware of the histologic characteristics of this lesion, to avoid misdiagnosis as a nonspecific cyst. (Turkiye Parazitol Derg 2016; 40: 51-3).

Keywords: Echinococcosis, hydatid cyst, prostate, heart

Received: 27.06.2015

Accepted: 29.02.2016

\section{ÖZ}

Bu makalede, biri 64 yaşında erkek, diğeri 35 yaşında kadın olan iki ayrı hastada sıra dışı yerleşim gösteren tek bir hastalık, kistik ekinokokkoz sunulmaktadır. Erkek hastanın iskemik koroner hastalığı nedeniyle yapılan genel kontrolleri sırasında, ultrasonografi sonucu prostat ve vezikula seminalisler arasında kistik kitle saptanmıştır. Diğer hasta ise kardiyopulmoner şikâyetleri nedeniyle hastaneye başvurmuş, görüntüleme yöntemleri ile kalp ventrikülleri arasında kistik bir lezyon belirlenmiştir. Her iki hastada lezyonlar rezeke edilmiş, histolojik inceleme sonucu kistik ekinokokkoz enfeksiyonu tanısı verilmiştir. Endemik bölgelerde alışılagelmiş lokalizasyonlarda sıklıkla görülmekle birlikte, bu kistlerin sıra dışı yerleşim gösterebileceği ve bu nedenle spesifik olmayan kistlerle karışabileceği akılda tutulmalıdır.

(Turkiye Parazitol Derg 2016; 40: 51-3).

Anahtar Kelimeler: Ekinokokkoz, kist hidatik, prostat, kalp

Geliş Tarihi: 27.06.2015

Kabul Tarihi: 29.02 .2016

\section{INTRODUCTION}

Cystic echinococcosis (hydatid cyst) is a parasitic disease caused by infection with the larval stage of Echinococcus granulosus, a 2-7 millimeter long tapeworm found in dogs (definitive host) and sheep, cattle, goats, and pigs (intermediate hosts). Humans are infected by the ingestion of parasite eggs through contaminated food or water or through a direct contact with animal hosts. Most infections in humans are asymptomatic for many years until cysts grow to an extent that triggers clinical signs.

Cystic echinococcosis in endemic areas is common in routine surgical pathology practice. In general, the cysts are most commonly located in the liver and lungs. They are usually diagnosed under detailed pathologic evaluation and clinicopathologic correlation. However, in lesions mimicking hydatid cysts, particularly in unusual sites, both the

Address for Correspondence / Yazışma Adresi: Dr. Yeşim Sağlıcan E.mail: yesim.saglican@acibadem.com.tr DOI: 10.5152/tpd.2016.4378

CCopyright 2016 Turkish Society for Parasitology - Available online at www.tparazitolderg.org

CTelif hakkı 2016 Türkiye Parazitoloji Derneği - Makale metnine www.tparazitolderg.org web sayfasından ulaşılabilir. 
imaging techniques and histopathologic examination can lead to inappropriate differential diagnosis. Here we present two cases of cystic echinococcosis with their clinical and histopathologic appearance and a brief literature review.

\section{CASE REPORT}

\section{Case 1}

A 64-year-old man was followed up for ischemic coronary disease. During the last consultation, a well-limited, 65-mm mass composed of cystic and solid components at the posterior of the urinary bladder was detected using abdominal ultrasonography. Its association with prostate or seminal vesicle was not well defined using ultrasonography. Both urinary system and transrectal ultrasonography showed a cystic and semisolid mass measuring $155 \mathrm{~mL}$ in volume that was closely associated with prostate and seminal vesicles. Initial diagnosis was done using trucut needle biopsy and aspiration of the cyst fluid. Microscopically, the sections showed fibromuscular prostatic tissues and isolated thick fibrous cyst wall fragments without any cellular lining and dispersed multinuclear histiocytic giant cells in the wall (Figure 1). Cytospin preparations of the cyst fluid showed proteinous secretion, nuclear debris, and spermatozoa. The diagnosis was benign cyst wall consistent with either a prostatic cyst or seminal vesicle cyst.

Based on these findings, transurethral prostatectomy was performed. The resected tissues were $23 \mathrm{gm}$ in weight and $6.5 \times 6 \times 0.6$ $\mathrm{cm}$ in dimensions. Along with the prostatic tissues were $4 \times 3.5 \times 0.5$ $\mathrm{cm}$ pearly membranous tissues. Microscopic sections revealed cellular, lamellous cyst wall fragments consistent with cuticula between the prostatic tissues, but no scolex was detected (Figure 2).

\section{Case 2}

A 35-year-old female presented with palpitation and dyspnea. Echocardiography and cardiac MRI revealed a 5-6 cm interventricular septal cardiac cyst. The patient was prepared for surgery after a preoperative diagnosis of hydatid cyst. At the beginning of surgery, transesophageal echocardiography was performed to verify the localization of the lesion; it was located at the septum, bulging toward the posterior wall of the ventricle. The cyst fluid was aspirated, and the wall was resected from the septum.

On gross examination, the specimen consisted of membranous calcified tissues and cuticular membrane. Histologic sections revealed, a diffusely calcified and inflamed fibrous capsule containing residual muscle of the heart at the outer portion. There were acellular, laminated chitinous membrane and degenerated germinal layer at the inner wall of the fibrous capsule (Figure 3). A few scolices were also detected (Figure 4).

\section{Outcome}

Both the lesions were diagnosed as cystic echinococcosis; one of them in the prostate and the other in the heart. AntiEchinococcus total antibody was found to be elevated on serologic examinations, and allergic laboratory tests showed high levels for specific anti-Echinococcus IgE antibodies in both patients. Other organs were scanned to locate the primary site of the disease or to identify haematogenous spread of Echinococcus. A calcified cystic lesion consistent with hydatid cysts was found in the liver of case 1; however, results from the imaging techniques were within normal limits in case 2 and no other focus was detected. Albendazole was used after surgery,

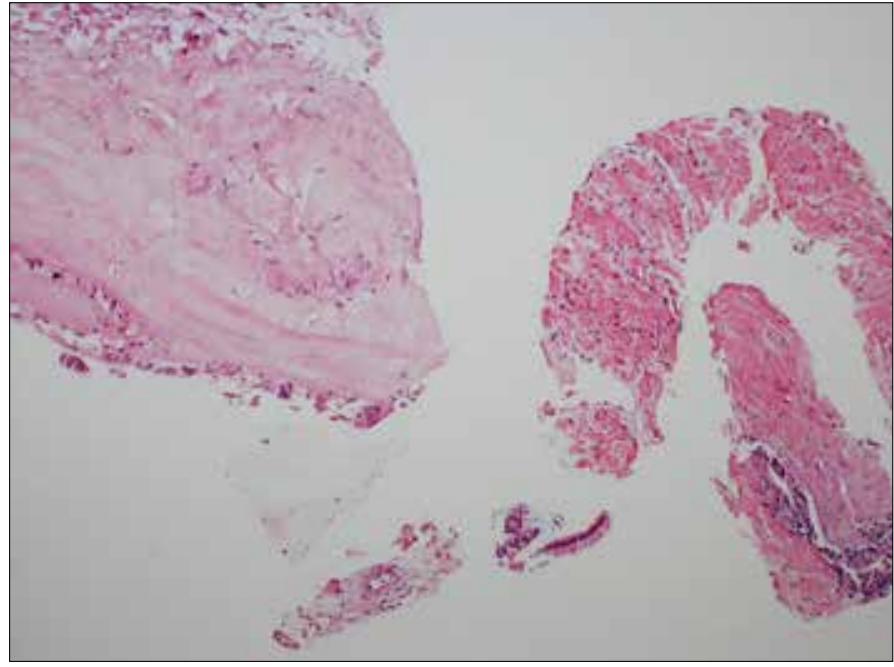

Figure 1. Trucut needle biopsy revealed prostatic tissues and isolated thick fibrous cyst wall fragments $(H \& E, \times 100)$

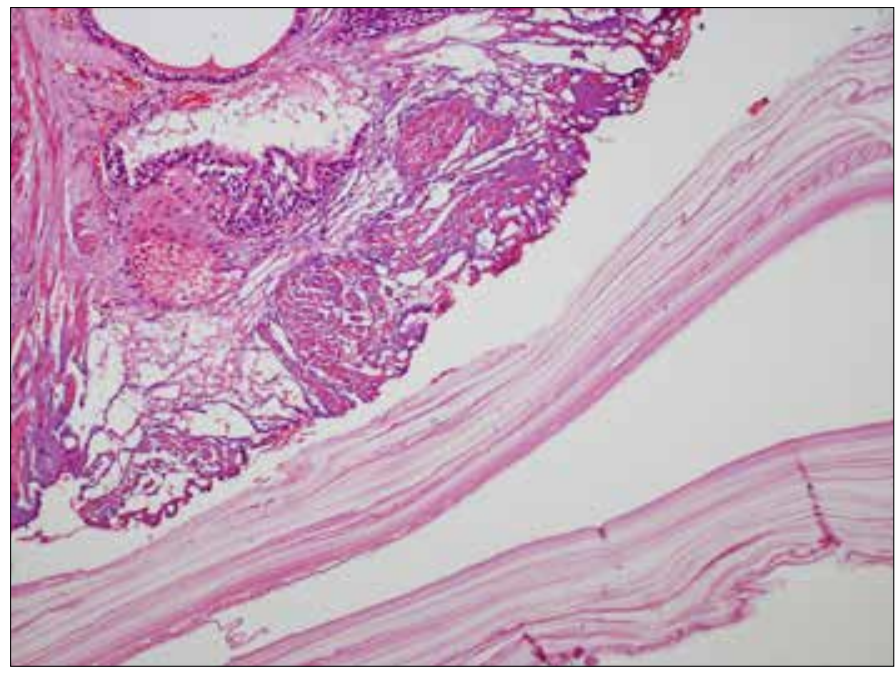

Figure 2. Transurethral resection specimen of the prostate; prostate tissue (left) and a cellular, lamellous cyst wall (right) $(H \& E, \times 100)$

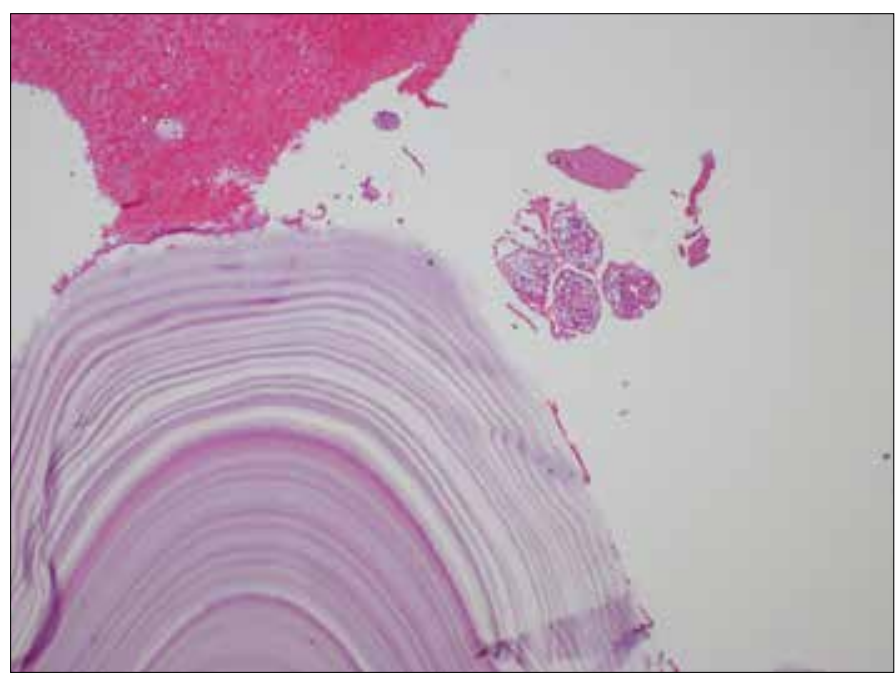

Figure 3. Cardiac cyst wall consists of a laminated chitinous membrane and few scolices $(H \& E, \times 100)$ 


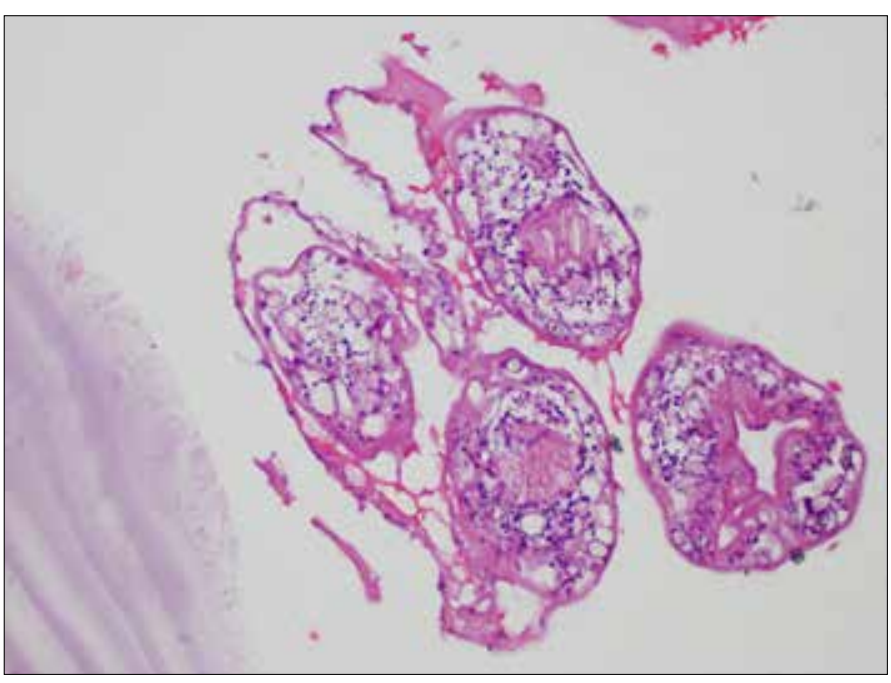

Figure 4. Scolices within the cyst $(H \& E, \times 200)$

and there was no evidence of the hydatid disease at their postoperative 1 year follow-up.

\section{DISCUSSION}

Echinococcal infection is caused by hydatid tapeworm, mostly $E$. granulosus (99\%) (1). It is a common disease particularly in the Middle East, Greece, Australia, North Africa, and some parts of South America (2). It may occur at any age and most commonly involves the liver (50\%-70\%) followed by the lungs (11\%-17\%) (1, 2). Compared with the heart, prostatic or seminal vesicle hydatid cysts are less common $(3,4)$. Davies $(5)$ referred to the history of cystic echinococcosis and related it to the time of Hippocrates, but probably the early cases related to the prostate were reported by Plaggmeyer and Cumming in 1922. Subsequently, more cases were reported that included the kidney, spleen, urinary bladder, bone, retrovesical, and spinal cysts (4, 6-9).

Clinical manifestations of hydatid disease were variable, and some of them were incidentally detected during radiologic investigations. Ultrasonography and computerized tomography (CT) cannot always reliably distinguish these lesions from other cystic lesions, such as congenital mullerian remnant cysts, retention cysts, and even cystic degeneration of prostatic hyperplasia. Differential diagnosis should include simple cysts, cystadenomas, and teratoma. Tumors and aneurysms of the heart should also be considered. Causes of diagnostic mistakes using CT include early disease stage, small cyst size, features of localization, and lack of daughter cysts. Cysts can be primary in these locations, but in published reports, they are mostly believed to have an origin from other usual locations (1). Serologic findings are about $90 \%$ sensitive for E. granulosus; however, false-positive results do occur. Definitive diagnosis is based on cyto-histologic findings; a meticulous search for acid-fast birefringent hooklets or laminated membrane is mandatory.

Cystic hydatid disease has generally been treated with surgical resection. The introduction of other interventional methods, such as percutaneous drainage, combined with albendazole therapy is an effective alternative treatment, particularly for hydatid cysts of the liver. Surgery with the pre- and post-operative administration of albendazole is the best treatment option (10).

\section{CONCLUSION}

An awareness of the existence of these lesions even in endemic areas and a careful focus on key histologic characteristics will aid pathologists in appropriate diagnosis.

Ethics Committee Approval: Was not obtained.

Informed Consent: Was not obtained.

Peer-review: Externally peer-reviewed.

Author contributions: Consept - Y.S., Ö.Y.; Design - Y.S.; Supervision Ö.Y.; Funding - Y.S.; Ö.Y., E.K.; Materials - Y.S.; Ö.Y., E.K.; Data Collection and/or Processing - Y.S.; Ö.Y., E.K.; Analysis and/or Interpretation - Y.S.; Literature Review - Y.S., E.K; Writer - Y.S., Critical Review - Ö.Y., E.K.

Conflict of Interest: No conflict of interest was declared by the authors.

Financial Disclosure: The authors declared that this study has received no financial support.

\section{Etik Komite Onayı: Alınmadı.}

Hasta Onamı: Hastalar biyopsi alınırken dokularının arşivimizde saklandığını ve her türlü çalışma için parafin bloklarının kullanılacağını bildiklerinden dolayı, hasta onamı alınmamıştır.

Hakem Değerlendirmesi: Dış Bağımsız.

Yazar Katkıları: Fikir - Y.S., Ö.Y.; Tasarım - Y.S ; Denetleme Ö.Y.; Kaynaklar - Y.S.; Ö.Y., E.K.; Malzemeler Y.S., Ö.Y., E.K.; Veri Toplanması ve/veya işlemesi - Y.S., Ö.Y., E.K.; Analiz ve/veya Yorum - Y.S.; Literatür taraması - Y.S., E.K.; Yazıyı Yazan - Y.S.; Eleştirel İnceleme - Ö.Y., E.K.

Çıkar Çatışması: Yazarlar herhangi bir çıkar çatışması bildirmemişlerdir.

Finansal Destek: Yazarlar bu çalışma için finansal destek almadıklarını beyan etmişlerdir.

\section{REFERENCES}

1. Desmet VJ, Rosai J. Liver; Echinococcuscyst (hydatidcyst). Rosai J, editor. Rosai and Ackerman's Surgical Pathology, 10th ed. New York: Elsevier Mosby; 2011. p. 915-6.

2. Washington K. Masses of the liver; Cystic masses. Mills SE, editor. Sternberg's Diagnostic Surgical Pathology, 6th ed. Philadelphia: Wolters Kluwer Health; 2015. p. 1708-9.

3. Ipek G, Omeroglu SN, Goksedef D, Balkanay OO, Kanbur E, Engin $E$, et al. Large cardiac hydatid cyst in the interventricular septum. Tex Heart Inst J 2011; 38: 719-22.

4. Izol V, Eken A, Aridogan IA, Koltas S, Tansug Z. Acute urinary retention due to cystic echinococcosis: A case report. Can Urol Assoc J 2012; 6: 192-4. [CrossRef]

5. Davies JA. Echinococcal cyst arising from the prostate. Can Med Assoc J 1946; 54: 268-71.

6. Bostwick DG. Seminal vesicles; Congenital and acquired malformations: Cyts. Bostwick DG, Cheng L, editors. Urologic Surgical Pathology, 3rd ed. Philadelphia: Elsevier Saunders; 2014. p. 535-6.

7. Ercil H, Gurlen G, Sener NC. A rare cause of lower urinary tract symptoms: retrovesical hydatid cyst. JPMA 2014; 64: 1087-9.

8. Doğanavşargil B, Ayhan E, Argin M, Pehlivanoğlu B, Keçeci B, Sezak $M$, ve ark. Cystic bone lesions: Histopathologic spectrum and diagnostic challenges. Turkish J Pathol 2015; 31: 95-103.

9. Çakıcı M, Çetin M, Süner A, Polat M. Isolated multiple invasive cardiac hydatid cyst. CausaPedia 2013; 2: 245.

10. Gavara CG, Lopez-Andujar R, Ibanez TB, Angel JMR, Herraiz AM, Castellanos FO, et al. Review of the treatment of liver hydatid cysts. World J Gastroenterol 2015; 7; 21: 124-31. [CrossRef] 